\title{
Remarks about type specimens of Cicindela elisae Motschulsky, 1859 and Cicindela amurensis Morawitz, 1862 (Coleoptera: Cicindelidae)
}

\section{Заметки о типах Cicindela elisae Motschulsky, 1859 и Cicindela amurensis Morawitz, 1862 (Coleoptera: Cicindelidae)}

\author{
Andrey V. Matalin ${ }^{1,2}$ \\ A.B. Маталин ${ }^{1,2}$

\begin{abstract}
${ }^{1}$ Moscow State Pedagogical University, Education-Scientific Centre of Ecology \& Biodiversity, Kibalchicha str. 6, build. 3, 129164, Moscow, Russia. E-mail: andrei-matalin@yandex.ru

${ }^{1}$ Московский педагогический государственный университет, Учебно-научный центр экологии и биоразнообразия, ул. Кибальчича, д. 6, корп. 3, 129164 Москва, Россия.

${ }^{2}$ Pirogov Russian National Research Medical University, Pediatric Faculty, Department of Biology, Ostrovitianova str. 1, 117997 Moscow, Russia. биологии, ул. Островитянова, д. 1, Москва 117997, Россия.
\end{abstract} \\ 2 Российский национальный исследовательский медицинский университет им. Н.И. Пирогова, педиатрический факультет, кафедра
}

KEY WORDS. Cicindelidae, Cicindela elisae, Cicindela amurensis, lectotypes, paralectotypes. КЛЮЧЕВЫЕ СЛОВА. Cicindelidae, Cicindela elisae, Cicindela amurensis, лектотипы, паралектотипы.

ABSTRACT. According to study of the type specimens of Cicindela elisae Motschulsky, 1859 and Cicindela amurensis Morawitz, 1862 their conspecificity is established and their synonymy is reconfirmed. The lectotypes and paralectotypes of Cicindela elisae Motschulsky, 1859 and Cicindela amurensis Morawitz, 1862 are designated as well.

РЕЗЮМЕ. По результатам изучения типовых экземпляров Cicindela elisae Motschulsky, 1859 и Cicindela amurensis Morawitz, 1862 г. установлена их конспецифичность и подтверждена синонимия. Обозначены лектотипы и паралектотипы Cicindela elisae Motschulsky, 1859 и Cicindela amurensis Morawitz, 1862.

Motschulsky [1859] described his Cicindela elisae from the Amur River, indicating that the type locality ranged from the mouth of Shilka River to Nikolayevsk. Three years later, Morawitz [1862] described his Cicindela amurensis from localities near the junctions of Sungari and Amur rivers, as well as of the Ussuri and Amur rivers. Shortly after that, Motschulsky [1864] noted that $C$. elisae had been described once more, under the name of $C$. amurensis, by Morawitz [1862], thus establishing the synonymy of $C$. elisae and $C$. amurensis. Some subsequent researchers shared that point of view [Horn, 1915, 1926; Matsumura, 1928; Lafer, 1978; Kryzhanovskij et al., 1995; Lorenz, 1998], while some others considered both as two subspecies of
Cylindera (Eugrapha) elisae (Motschulsky, 1859) [Horn, Roeshke, 1891; Mandl, 1981; Werner, 1992; Wiesner, 1992, 2020; Puchkov, Matalin, 2003, 2017; Lorenz, 2005; Makarov et al., 2020]. Unfortunately, none of the mentioned above authors has designated the types of these taxa.

\section{Material and methods}

The studied type specimens are deposited in the Zoological Museum of the Moscow State University, Moscow, Russia (ZMMU), in the Zoological Institute of the Russian Academy of Science, St. Petersburg, Russia (ZISP), and in the Moscow State Pedagogical University (MSPU).

The measurements (in $\mathrm{mm}$ ) were made with an ocular-micrometer mounted on a Leica M165c (Carl Zeiss) stereomicroscope, as follows: TL — total body length without labrum (from anterior margin of clypeus to the elytral apex along the suture), LL — length of labrum with apical teeth (along the midline), LW width of labrum (in the widest place), PL - length of pronotum (along the midline), PW - width of pronotum (in the widest place), EL - length of elytra (from the base of scutellum along the suture), EW - width of elytra (in the widest place), AL — length of aedeagus (from the base to the apex).

The photographs of the habitus and the details of all studied specimens were taken with a Canon EOS 5D

How to cite this article: Matalin A.V. 2021. Remarks about type specimens of Cicindela elisae Motschulsky, 1859 and Cicindela amurensis Morawitz, 1862 (Coleoptera: Cicindelidae) // Russian Entomol. J. Vol.30. No.1. P.20-24. doi: 10.15298/rusentj.30.1.04 
Mark III camera with a Canon MP-E $65 \mathrm{~mm}$ macro lens. The slides of the male genitalia were photographed with a Canon EOS 6D camera, attached to a Zeiss Axio Scope.A1 microscope. In both cases, the extended focus technique was used. All pictures were processed using Zerene Stacker software. For preparing the slides, the aedeagi of male specimens were consistently kept in 10\% $\mathrm{KOH}$ (24 h.), 4\% acetic acid (5 min.) and cold water (5 min.), and then mounted with Hoyer fluid or Euparal (D 1.05) media.

\section{Results}

In the collection of ZMMU three badly damaged specimens of $C$. elisae with the original labels of $\mathrm{V}$. Motschulsky are survived, while in the collection of ZISP four syntypes of $C$. amurensis with the original labels of A. Morawitz were found. A comparison of the type specimens of C. elisae (Figs 1-8) and C. amurensis

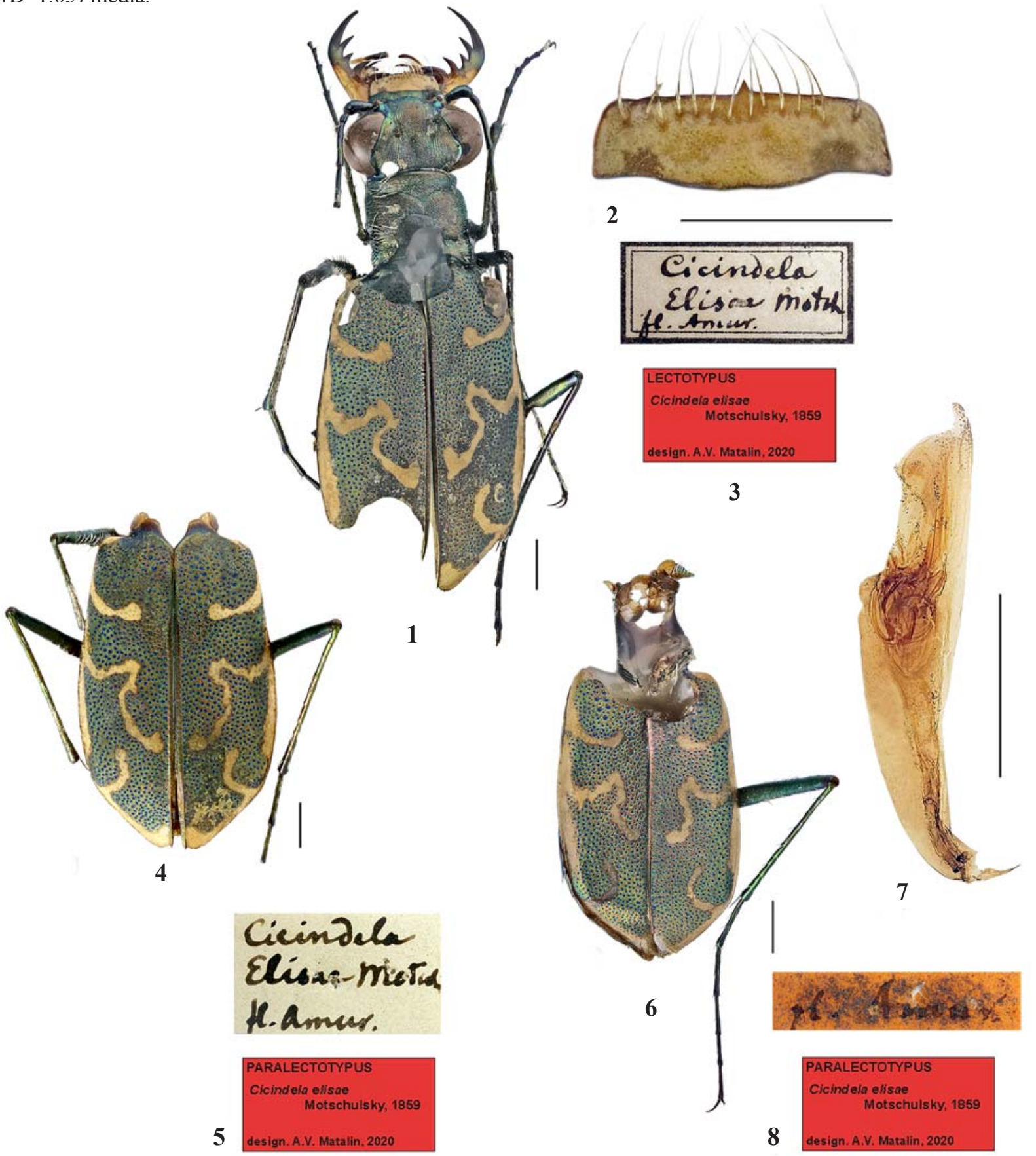

Figs 1-8. Type specimens of $C$. elisae: 1, 4, 6 - habitus; 2 - labrum, 7 - aedeagus; $3,5,8$ - labels; 1-3 - lectotype; 4-8 paralectotypes; $1-5$ - females; $6-8$ - male. Scale bars: $1.0 \mathrm{~mm}$.

Рис. 1-8. Типовые экземпляры C. elisae: $1,4,6$ - габитус; 2 - верхняя губа, 7 - эдеагус; 3, 5, 8 - этикетки; $1-3$ - лектотип; 4-8 - паралектотипы; 1-5 - самки; 6-8 - самец. Масштаб: 1,0 мм. 
(Figs 9-19) confirms their conspecificity, because the main dimensions (Table; Fig. 20), proportions (Fig. 21 ), coloration and white elytral pattern as well as the shape of the aedeagus are corresponded to the variability within the same taxon. Thus, the synonymy of $C$. elisae and $C$. amurensis established by Motschulsky
[1864] is reconfirmed.

In order to support the stability of the nomenclature and according to the Articles 72.1, 72.5, 72.9, 74.1 and 74.7 of the ICZN [1999], the lectotypes and paralectotypes of both these taxa are designated below.

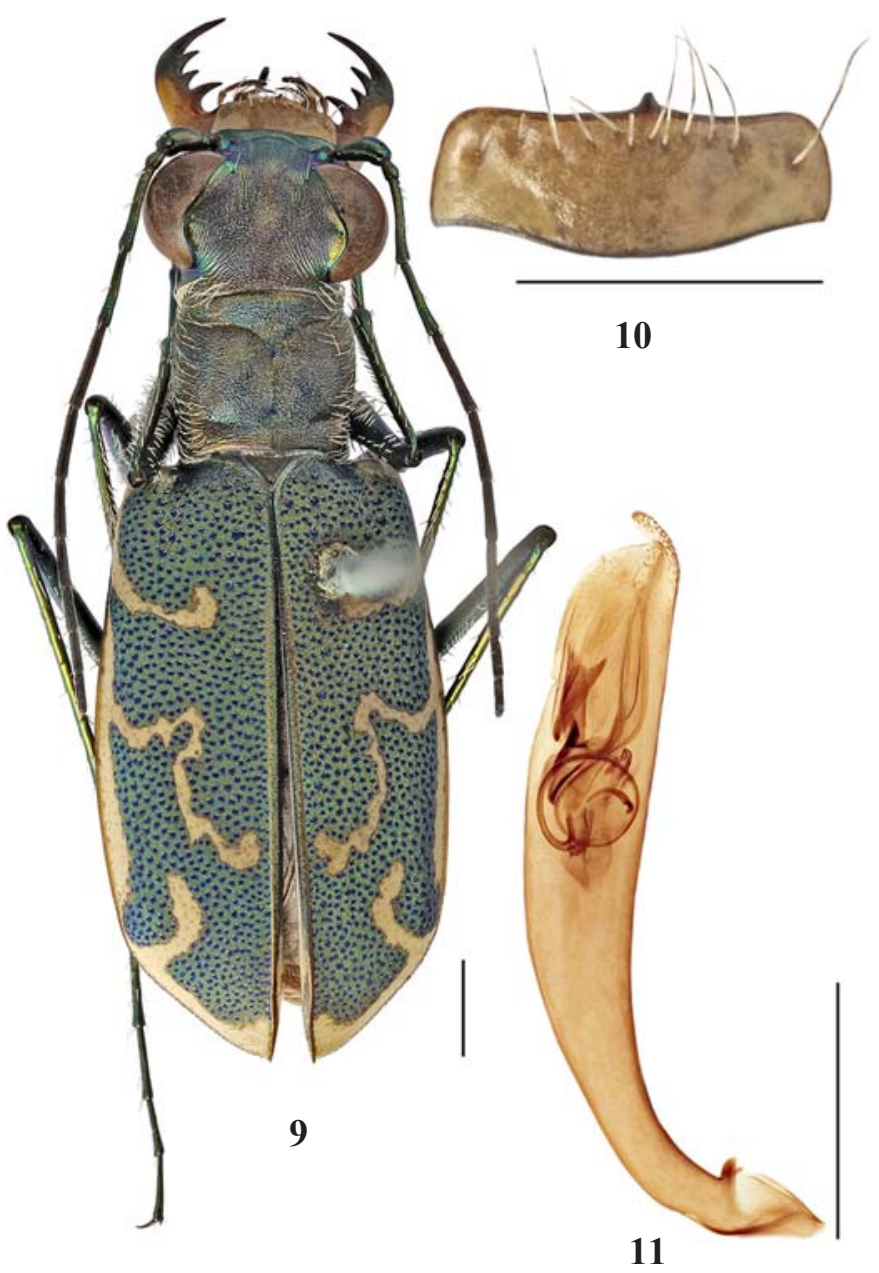

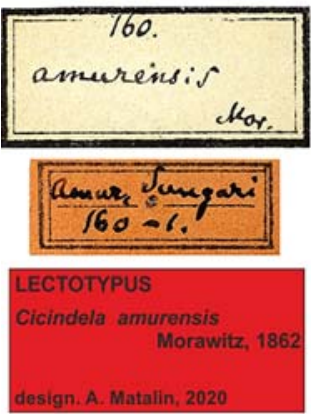

12
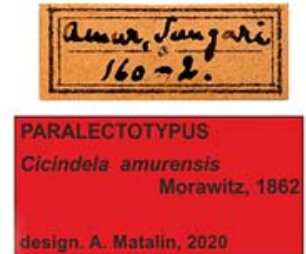

15

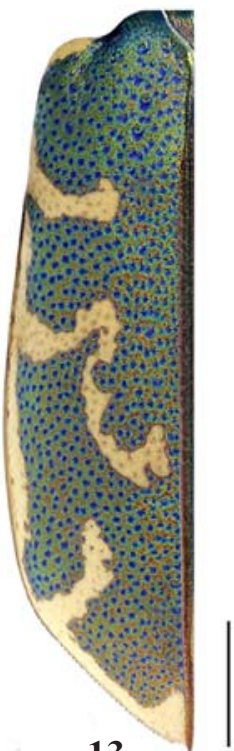

13

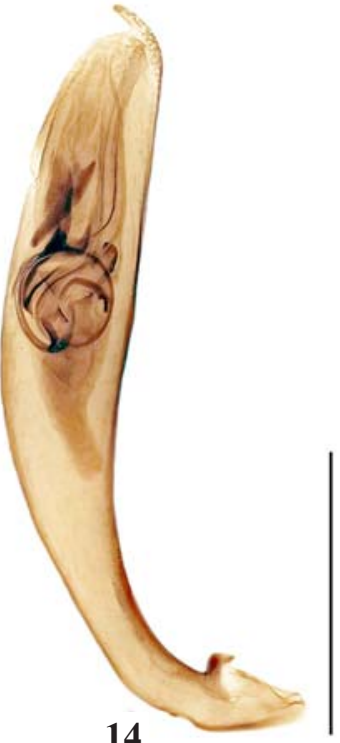

14

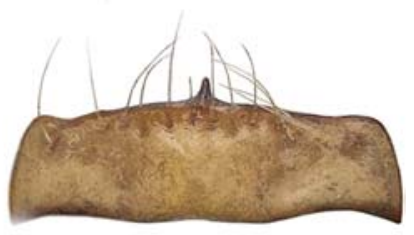

17

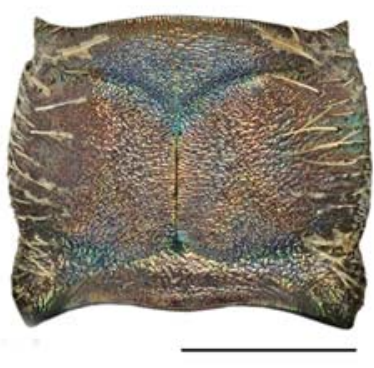

18

Figs 9-19. Type specimens of $C$. amurensis. 9 - habitus; 10,17 - labrum; 11,14 - aedeagus; 13,16 - left elytron; 18 - pronotum; 12, 15, 19 - labels; 9-12 - lectotype; 13-19 - paralectotypes; 9-15 - males; 16-19 - female. Scale bars: $1.0 \mathrm{~mm}$.

Рис. 9-19. Типовые экземпляры C. amurensis. 9 - габитус; 10,17 - верхняя губа; 11,14 - эдеагус; 13,16 - левое надкрылье; 18 - переднеспинка; 12, 15, 19 - этикетки; 9-12 - лектотип; 13-19 - паралектотипы; 9-15 - самцы; 16-19 - самка. Масштаб: 1,0 мм. 

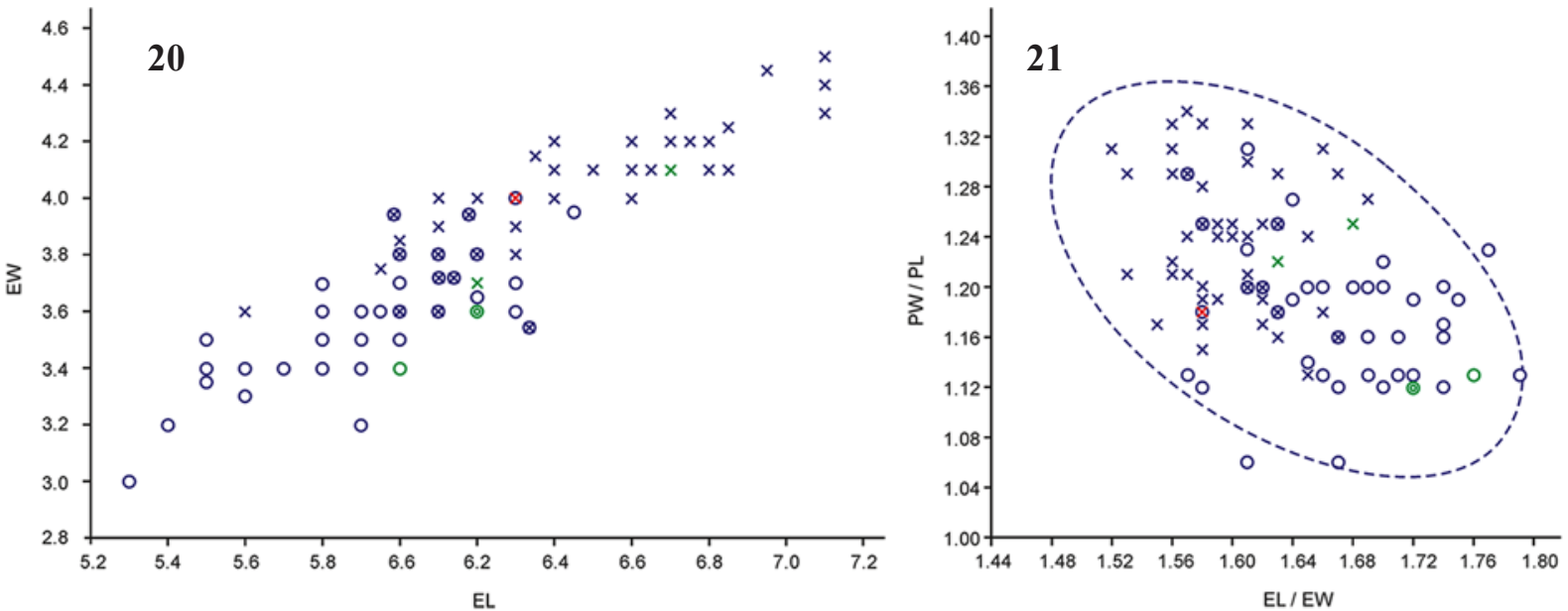

Figs 20-21. Variation in size and proportion of Cylindera (Eugrapha) elisae elisae: 20 - correlation of elytra length and width; 21 relation of the proportions of pronotum and elytra; circles — males; crosses — females; red cross - lectotype of C. elisae; green crosses and simple green circle - paralectotypes of C. amurensis; double green circle - lectotype of C. amurensis; dotted oval — $95 \%$ concentration ellipse.

Рис. 20-21. Изменчивость размеров и пропорций Cylindera (Eugrapha) elisae elisae: 20 - соотношение длины и ширины надкрылий; 21 - соотношение пропорций переднеспинки и надкрылий; кружки - самцы; кресты — самки; красный крест — лектотип C. elisae; зелёные кресты и простой зелёный кружок — паралектотипы C. amurensis; двойной зелёный кружок — лектотип C. amurensis; пунктирный овал - 95\% область значений.

\section{Cylindera (Eugrapha) elisae elisae}

(Motschulsky, 1859)

Cicindela elisae Motschulsky, 1859: 487.

= Cicindela amurensis Morawitz, 1862: 238.

TYPE MATERIAL. The lectotype of Cicindela elisae Motschulsky, 1859 (designated herewith), + (without $10^{\text {th }}-11^{\text {th }}$ right and $5^{\text {th }}$ $11^{\text {th }}$ left antennomeres, $4^{\text {th }}-5^{\text {th }}$ left fore-tarsomeres, left hind tibia and tarsus, as well as abdomen; with head, prothorax, left femur, elytral base and apex of left elytron damaged by dermestid larvae) "Cicindela Elisae Motsch., fl. Amur" [handwritten white label], "Lectotypus, Cicindela elisae Motschulsky, 1859, design. A.V. Matalin, 2020" [printed red label] (ZMMU). Paralectotypes of Cicindela elisae Motschulsky, 1859 (designated herewith): O' (without head, fore-, middle and left hind legs; with pronotum, base of elytra and apex of right elytron damaged by dermestid larvae) — "fl. Amur" [handwritten red label], "Paralectotypus, Cicindela elisae Motschulsky, 1859, design. A.V. Matalin, 2020" [printed red label]; 우 (witout head, prothorax, both fore-, right middle and left hind legs; with $5^{\text {th }}$ $6^{\text {th }}$ abdominal sternites and genitalia damaged by dermestid larvae) "Cicindela Elisae Motsch., fl. Amur" [handwritten white label], "Paralectotypus, Cicindela elisae Motschulsky, 1859, design. A.V. Matalin, 2020" [printed red label] (both in ZMMU, Figs 1-8).

The lectotype of Cicindela amurensis Morawitz, 1862 (designated herewith): $\sigma^{7}$ (without hind right tarsus) — "Amur, Sungari, 160-1" [handwritten pink label], "Lectotypus, Cicindela amurensis Morawitz, 1862, design. A.V. Matalin, 2020" [printed red label]
(ZISP); Paralectotypes of Cicindela amurensis Morawitz, 1862 (designated herewith): $\sigma^{7}$ — "Amur, Sungari, 160-2" [handwritten pink label], "Lectotypus, Cicindela amurensis Morawitz, 1862, design. A.V. Matalin, 2020" [printed red label]; ㅇ — "Amur, Sungari, 160-3" [handwritten pink label], "Lectotypus, Cicindela amurensis Morawitz, 1862, design. A.V. Matalin, 2020" [printed red label]; + (without $10^{\text {th }}-11^{\text {th }}$ left antennomeres) - "Ussuri, 160 4" [handwritten pink label], "Lectotypus, Cicindela amurensis Morawitz, 1862, design. A.V. Matalin, 2020" [printed red label] (all in ZISP, Figs 9-19).

\section{Discussion}

Due to the widespread from the Amur River valley through Mongolia, Korea and China including Sakhalin, Kunashir, Taiwan and different Japanese Islands [Puchkov, Matalin, 2017] to northern Vietnam [Wiesner et al., 2017], Cylindera (Eugrapha) elisae (Motschulsky, 1859) is characterized by the high variability. The coloration and the white pattern of elytra are traditionally used for the separation of its local forms. Considering the synonymy of $C$. elisae and C. amurensis, nine subspecies are known now: C. e. formosana (Minowa, 1932) and C. e. reductelineata (W. Horn, 1912) - in

Table. The dimensions of the type specimens of $C$. elisae and $C$. amurensis. Таблица. Размеры типовых экземпляров C. elisae и C. amurensis.

\begin{tabular}{|c|c|c|c|c|c|c|c|c|c|}
\hline Specimens & Sex & $\mathrm{TL}$ & $\mathrm{LL}$ & LW & $\mathrm{PL}$ & $\mathrm{PW}$ & EL & EW & $\mathrm{AL}$ \\
\hline \multicolumn{10}{|c|}{ C. elisae } \\
\hline lectotype & 9 & 9.8 & 0.5 & 1.4 & 1.7 & 2.0 & 6.3 & 4.0 & \\
\hline paralectotype & $\underline{Q}$ & & & & & & 6.1 & 3.8 & \\
\hline paralectotype & $\delta$ & & & & & & 5.4 & 3.3 & 2.6 \\
\hline \multicolumn{10}{|c|}{ C. amurensis } \\
\hline lectotype & 8 & 9.5 & 0.5 & 1.3 & 1.7 & 1.9 & 6.2 & 3.6 & 2.8 \\
\hline paralectotype & $\hat{\delta}$ & 9.2 & 0.4 & 1.3 & 1.6 & 1.8 & 6.0 & 3.4 & 2.6 \\
\hline paralectotype & 9 & 10.1 & 0.5 & 1.5 & 1.8 & 2.2 & 6.7 & 4.1 & \\
\hline paralectotype & q & 9.5 & 0.4 & 1.3 & 1.6 & 2.0 & 6.2 & 3.7 & \\
\hline
\end{tabular}


Taiwan; C. e. mikurana (Nakane, 1968 ) and C. e. novitia (Bates, 1883) - in Japan; C. e. koreanica (Mandl, 1981) - in South Korea; C. e. atroelytrata (Mandl, 1981) - in Chinese province Shaanxi; C. e. hulunbeierensis (Li, 1992) - in Chinese Inner Mongolia Autonomous Region; C. e. kunashirensis Pütz et Wiesner, 1995 - in Kunashir Island, and nominal subspecies in Mongolia, Russian Far East (including Sakhalin and Kunashir Islands), North and South Korea, most provinces of China as well as northern Vietnam [Puchkov, Matalin, 2017; Wiesner et al., 2017; Makarov et al., 2020]. However, according to the analysis of the sequences of the $28 \mathrm{~S}$ rDNA and COI genes some of the insular and mainland subspecies of $C$. elisae actually can be no more than the variations [Sota et al., 2011; Makarov et al., 2020]. The additional researches need to resolve this problem.

Acknowledgements. I am very grateful to A.A. Gusakov (Moscow, Russia) and B.M. Kataev (Saint Petersburg, Russia) who kindly loaned the type specimens for my study, as well as to Sergei Golovatch (Moscow, Russia) for checking the English.

\section{References}

Horn W. 1915. Coleoptera Adephaga, fam. Carabidae, subfam. Cicindelinae // P. Wytsman (ed.). Genera Insectorum. Vol.82. P.209-486 + P1.16-23.

Horn W. 1926. Carabidae, Cicindelinae // Schenkling S., Junk W. (Hrsg.). Coleopterorum Catalogus. Pr.86. Berlin: W. Junk. S.1345.

Horn W., Roeshke H. 1891. Monographie der paläarktischen Cicindelen. Analytisch bearbeitet mit besonderer Berücksichtigung der Variationfahigkeit und geographischen Verbreitung. Berlin. 199 pp.

ICZN. 1999. International Code of Zoological Nomenclature. Fourth Edition. The International Trust of Zoological Nomenclature. London. xxix +306 pp.

Kryzhanovskij O.L., Belousov I.A., Kabak I.I., Kataev B.M., Makarov K.V., Shilenkov V.G. 1995. A checklist of the ground-beetles of Russia and adjacent lands (Insecta, Coleoptera, Carabidae). Sofia-Moscow: Pensoft Publishers. 271 pp.

Lafer G.Sh. 1978. [Review of the tiger beetles (Coleoptera, Carabidae) of Far East of the USSR] // Ivliev L.A., Paschenko N.F., Simakova T.P. (eds.). Biology of some useful and harmful insects of the Far East. Vladivostok Dalnauka. P.3-18 [in Russian].

Lorenz W. 1998. Systematic list of extant ground beetles of the word (Insects Coleoptera "Geadephaga": Trachypachidae and Carabidae incl. Paussinae, Cicindelinae, Rhysodinae). First Edition. Tutzing. Germany. 503 pp.
Lorenz W. 2005. Systematic list of extant ground beetles of the word (Insects Coleoptera "Geadephaga": Trachypachidae and Carabidae incl. Paussinae, Cicindelinae, Rhysodinae). Second Edition. Tutzing. Germany. 530 pp.

Makarov K.V., Kryzhanovskij O.L., Belousov I.A., Zamotailov A.S., Kabak I.I., Kataev B.M., Shilenkov V.G., Matalin A.V., Fedorenko D.N., Komarov E.V. 2020. [Taxonomical list of ground beetles (Carabidae) of Russia]. Last updated: May 25, 2020 https://www.zin.ru/animalia/coleoptera/rus/car rus.htm [in Russian]

Makarov K.V., Sundukov Yu.N., Matalin A.V. 2020. Ground beethes (Coleoptera, Carabidae) in fumarole fields of Kunashir Island, Kuril Archipelago, Russia // Acta Zoologica Academiae Scientiarum Hungaricae. Vol.66(Suppl.). P.97-145. DOI: 10.17109/AZH.66.Suppl.97.2020.

Mandl K. 1981. Bearbeitung einer Cicindeliden-Sammlung aus Ländern des fernen Ostens und Beschreibung einer neuen Calosoma- (Charmosta-) Rasse (Col.) // Koleopterologische Rundschau. Bd.55. S.19-43.

Matsumura S. 1928. Catalogus Coleopterorum Japonicum // Insecta Matsumurana. Vol.2. No.4. P.210-213.

Morawitz A. 1862. Vorläufige Diagnosen neuer Coleopteren aus Südost-Sibirien // Bulletin de l'Académie Impériale des Sciences de Saint-Pétersbourg. Vol.4. P.180-228.

Motschulsky V.I. 1859. Catalogue des insectes rapportés des environs du fl. Amour, depuis la Schilka jusqu'à Nikolaévsk, examinés et énumérés // Bulletin de la Société Impériale des Naturalistes de Moscou. Vol.32. No.3. P.487-507.

Motschulsky V.I. 1864. Énumération des nouvelles espèces de coléoptères rapportés de ses voyages // Bulletin de la Société Impériale des Naturalistes de Moscou. Vol.37. No.3. P.171-240.

Puchkov A.V., Matalin A.V. 2003. Subfamily Cicindelinae Latreille, 1802 // Löbl I., Smetana A. (eds.). Catalogue of Palaearctic Coleoptera. Vol.1. Archostemata-Myxophaga-Adephaga. Stenstrup: Appolo Book. P.99-118.

Puchkov A.V., Matalin A.V. 2017. Subfamily Cicindelinae Latreille, 1802 // Löbl I., Löbl D. (eds.). Catalogue of Palaearctic Coleoptera. Vol.1. Revised and Updated Edition. Archostemata-Myxophaga-Adephaga. Leiden-Boston: Brill. P.217-249. https://doi.org/10.1163/9789004330290.

Sota T., Liang H., Enokido Y., Hori M. 2011. Phylogeny and divergence time of island tiger beetles of the genus Cylindera in East Asia // Biological Journal of the Linnean Society. Vol. 102. P.715-727. https://doi.org/10.1111/j.1095-8312.2011.01617.x.

Werner K. 1992. Cicindelidae. Regionis Palaearcticae. Cicindelini 2: Cosmodela-Platydela-Lophyra-Habrodera-ChaetoderaNeolaphyra-Cephalota-Cassolai-Homodela-Cylindera-Eugrapha-Myriochile-Salpingophora-Hypaeta-Abroscelis-Callytron // Die Käfer der Welt, The Beetles of the World. Sciences Nat. France. Vol.15. P.1-94.

Wiesner J. 1992. Verzeichnis der Sandlaufkäfer der Welt, Checklist of the Tiger Beetles of the World (Coleoptera, Cicindelidae). Keltern: Erna Bauer Verlag. 364 pp.

Wiesner J. 2020. Checklist of the Tiger Beetles of the World, $2^{\text {nd }}$ Edition. Borsdorf: Winterwork. 540 pp.

Wiesner J., Bandinelli A., Matalin A. 2017. Notes on the tiger beetles (Coleoptera: Carabidae: Cicindelinae) of Vietnam // Insecta Mundi. Vol.0589, P.1-131. 